\title{
Coronin 1A deficiency identified by newborn screening for severe combined immunodeficiency
}

\author{
Yael Dinur Schejter ${ }^{a, b, c *}$, Amarilla Mandola ${ }^{a, b}$, and Brenda Reid ${ }^{a}$
}

\begin{abstract}
Introduction: Coronin $1 \mathrm{~A}$ belongs to a large family of actin regulatory proteins with a role in $\mathrm{T}$ cell homeostasis. A role for coronin $1 \mathrm{~A}$ was also observed in macrophages, NK, and neuronal cells. To date, coronin $1 \mathrm{~A}$ deficiency has been described in relatively few patients with combined immunodeficiency.

Aim: We studied here the molecular and genetic basis of immunodeficiency detected by newborn screening for severe combined immunodeficiency.

Methods: Patient data was collected in accordance with REB approved protocols. Immune work up, including $T$ and $B$ cell proliferative responses and serum concentrations of immunoglobulins, was performed. Next generation sequencing techniques and cellular analyses were also utilized.

Results: The patient presented with T cell lymphopenia, reduction in $\mathrm{CD} 4{ }^{+} \mathrm{CD} 45 \mathrm{Ra}^{+}$cells and hypogammaglobulinemia. Uniquely, she also had persistent severe neutropenia. Whole exome sequencing and Sanger confirmation revealed a novel homozygous mutation in coronin $1 \mathrm{~A}$.

Conclusion: Coronin 1A deficiency can be detected after birth by $\mathrm{T}$ cell receptor excision circle-based newborn screening.

Statement of novelty: We report here a patient with a novel mutation in coronin $1 \mathrm{~A}$, identified during newborn screening with low $T$ cell receptor excision circle levels and neutropenia, which is a unique finding in this condition.
\end{abstract}

\section{Background}

Coronin 1A belongs to a large family of actin regulatory proteins which are highly conserved, from yeast to humans (Xavier et al. 2008). The human coronin 1A gene (CORO1A) maps to chromosome 16p11.2 and consists of 11 exons. It encodes a 461 amino acid, $57 \mathrm{kDa}$ actinbinding protein (Suzuki et al. 1995), and is expressed in various hematopoietic cells (Oku et al. 2003), as well as in the brain (Ahmed et al. 2007). Coronin 1A is believed to associate with polymerized actin and the actin branching facilitator actin-related protein $2 / 3$ complex (Arp2/3) (Rybakin and Clemen 2005; Föger et al. 2006). This protein has a clear role in $\mathrm{T}$ cell homeostasis both in mice and human (Shiow et al. 2008), although the exact mechanism is yet to be clarified. A role for coronin $1 \mathrm{~A}$ was also observed in macrophages (Jayachandran et al. 2007), NK (Mace and Orange 2014), and neuronal cells (Martorella et al. 2017).

Human coronin 1A deficiency was first described in a patient who presented with oral thrush, repeated
aDivision of Immunology and Allergy, Department of Paediatrics, The Hospital for Sick Children and the University of Toronto, Toronto, ON; ${ }^{\mathrm{b}}$ Canadian Centre for Primary Immunodeficiency, The Jeffrey Modell Research Laboratory for the Diagnosis of Primary Immunodeficiency, The Hospital for Sick Children, Toronto, ON; 'Department of Bone Marrow Transplantation and Cancer Immunotherapy, Hadassah Medical Center, Jerusalem, Israel
Submitted 15 January 2019

Accepted 20 February 2019

Available online 22 February 2019 
respiratory infections and disseminated chicken pox after varicella vaccine. The patient was found to have 2 null mutations in CORO1A. She had T cell lymphopenia and poor $\mathrm{T}$ cell responses to mitogens and antigens as well as poor humoral responses (Shiow et al. 2008, 2009).

Later on, several reported cases extended the spectrum of disease associated with mutations in CORO1A (Moshous et al. 2013; Mace and Orange 2014; Stray-Pedersen et al. 2014): hypomorphic mutations in 3 siblings were associated with a predisposition to EBV-mediated B cell lymphoproliferation and transformation into lymphoma at $12,7.5$, and 14 months, respectively (Moshous et al. 2013).

An additional kindred with a compound heterozygous mutation resulting in complete loss of protein expression (Stray-Pedersen et al. 2014) presented with a late onset disease at 7 years of age, with epidermodysplasiaverruciformis-human-papilloma-virus (EV-HPV), molluscum contagiosum and mucocutaneous herpetic ulcers, as well as granulomatous tuberculoid leprosy. Abnormalities in NK cell cytotoxic function in one of these patients were identified, and shown to be related to defects in regulation of the F-actin microenvironment, thus impeding lytic granule secretion (Mace and Orange 2014). Interestingly, both asymptomatic carrier parents were found to have immune abnormalities, including $\mathrm{CD}^{+}{ }^{+}$and NK cell lymphopenia.

The newborn screen (NBS) program for severe combined immunodeficiency (SCID) was initially implemented in Wisconsin in 2008 (Baker et al. 2010). Since then, similar programs were initiated in multiple states and world-wide (Kwan et al. 2014; Kanegae et al. 2016; Blom et al. 2017). The NBS program in Ontario, Canada, has been successfully implemented since 2013 (Cross 2013). The basis behind the successful NBS for SCID is the T cell receptor excision circles (TREC) assay (Accetta Pedersen et al. 2011). This assay involves an RT-PCR reaction to detect a TREC, which is a physiological byproduct of the $\mathrm{V}(\mathrm{D}) \mathrm{J}$ recombination process occurring in maturing thymocytes. Since TRECs do not replicate, they are a good biomarker of thymic output.

Several studies have retrospectively examined the yield of the TREC assay as a NBS for classical SCID as well as other conditions associated with $\mathrm{T}$ cell lymphopenia (Kwan et al. 2014; van der Spek et al. 2015). Low or undetectable TREC levels were found to have an excellent yield in the diagnosis of "typical SCID" (defined as autologous $\mathrm{T}$ cell count $<500$ cells $/ \mu \mathrm{L}$ and response to PHA proliferation of $<10 \%$ of normal (Roifman et al. 2012)), as well as some cases of combined immunodeficiency (CID) (autologous $\mathrm{T}$ cell count of $>500$ cells/ $\mu \mathrm{L}$ and reduced response to PHA proliferation). While prematurity is a common reason for low TREC numbers, repeating the test at a later age prevents unnecessary investigations. Pre- and perinatal medication use can also result in a false positive test, thus requiring prudence in interpretation of the test. Other causes for T cell lymphopenia included various syndromes, such as $\mathrm{Di}$ George syndrome/22q11.2 chromosome deletion, trisomy 21 , trisomy 18 , ataxia telangiectasia, CHARGE (coloboma, heart defect, atresia choanae, retarded growth and development, genital and ear abnormalities) syndrome and various less common entities. Importantly, identification of these syndromes, including CID, by NBS programs is not uniform. Depending of the cutoff for reporting of low TREC levels, variable numbers of infants are recognized as having idiopathic T cell lymphopenia, and required continued follow up and investigations for combined immunodeficiency.

We report here a case of coronin 1A deficiency caused by a novel homozygous mutation. The infant was detected to have profound $\mathrm{T}$ cell deficiency by TREC-based NBS.

\section{Methods}

\section{Patient}

Patient information was collected prospectively and retrospectively from medical records and entered to the Canadian Centre for Primary Immunodeficiency Registry (REB Protocol No. 100005598, The Hospital for Sick Children).

\section{Serum concentration of immunoglobulin and specific antibodies}

Serum concentrations of immunoglobulins were measured by nephelometry. Levels of serum antibodies to tetanus were measured by ELISA.

\section{$T$ and $B$ cell proliferative response}

Lymphocyte proliferative responses to mitogens including phytohemagglutinin (PHA) and anti-CD3. All assays were performed in triplicate and were compared with simultaneously stimulated normal controls, as previously described (Sharfe et al. 2014). 


\section{Exome sequencing and variant calling}

DNA from blood was submitted to The Centre for Applied Genomics (TCAG), Toronto, ON, Canada for exome library preparation and sequencing. DNA was quantified by Qubit DNA HS assay (Life Technologies, Carlsbad, CA, USA) and 100 ng of input DNA was used for library preparation using the Ion AmpliSeq Exome Kit (Life Technologies) according to the manufacturer's recommendations. The Ampliseq Exome library was immobilized on Ion $\mathrm{PI}^{\mathrm{TM}}$ Ion Sphere ${ }^{\mathrm{TM}}$ particles using the Ion PI Template OT2 200 Kit v3. Sequencing was performed with the Ion PI Sequencing 200 Kit v3 and Ion PI Chip v2 in the Ion Proton ${ }^{\mathrm{TM}}$ semiconductor sequencing system following the manufacturer's recommendation.

Alignment and variant calling were performed using Torrent Suite (v4.0) on the Ion Proton Server, using the Ion Proton Ampliseq germline low stringency setting and the hg19 reference genome. The variants were annotated using an in-house annotation pipeline (Stavropoulos et al. 2016) based on Annovar (November 2014 version) (Wang et al. 2010) and RefSeq gene models (downloaded from UCSC 1 August 2015).

\section{Sequencing analysis}

Patient's genomic DNA was extracted from peripheral blood lymphocytes using the Geneaid Genomic DNA
Mini Kit. Genomic DNA was amplified by PCR with specific primers designed upstream and downstream of the coronin 1A gene. Sequencing was done using GenomeLab Dye Terminator Cycle Sequencing (DTCS) Quick Start Kit (Beckman Coulter) and analyzed on CEQ 8000 Genetic Analysis System (Beckman Coulter).

\section{Western blotting}

Whole-cell lysates were prepared in a 1\% Triton X100 buffer and analyzed by Western blotting. Anti-coronin 1A antibodies were purchased from Creative Diagnostics Inc. and Gi 33 were purchased from Santa Cruz Biotechnology Inc.

\section{Case presentation}

The patient is a 14 month old female, born at term to a single mother of African descent. Perinatal history was unremarkable. There is no known consanguinity in the family. The patient's mother has a history of recurrent vaginal yeast infections and neutropenia. The patient was found to have low TREC values during NBS.

\section{Clinical course}

The patient's infectious history includes a coronavirus upper respiratory tract infection at 7 months of age, and recurrent thrush requiring oral fluconazole

Table 1: Patient immune work up.

\begin{tabular}{|c|c|c|}
\hline & Patient & Normal range \\
\hline WBC $\left(\times 10^{9} / L\right)$ & 1.83 & $6.0-13.0 \times 10^{9} / \mathrm{L}$ \\
\hline Neutrophils $\left(\times 10^{9} / \mathrm{L}\right)$ & 0.34 & $1.27-7.18 \times 10^{9} / \mathrm{L}$ \\
\hline Lymphocyte (×109/L) & 1.13 & $1.5-8 \times 10^{9} / \mathrm{L}$ \\
\hline \multicolumn{3}{|l|}{ Markers (cells/ $\mu \mathrm{L})$} \\
\hline $\mathrm{CD}^{+}$ & 367 & $1600-6700$ \\
\hline $\mathrm{CD}^{+}$ & 267 & $1000-4600$ \\
\hline $\mathrm{CD}^{+}$ & 40 & $400-2100$ \\
\hline $\mathrm{TCR} \gamma \delta$ & 75 & - \\
\hline CD19 ${ }^{+}$ & 183 & $600-2700$ \\
\hline $\mathrm{CD} 16 / 56^{+}$ & 187 & $200-1200$ \\
\hline TRECs (copies/0.5 $\mu \mathrm{g}$ DNA) & 382 & $>400$ \\
\hline Mitogenic response & (Stimulation index/control) & \\
\hline PHA & $642 / 659$ & $>350$ \\
\hline \multicolumn{3}{|l|}{ Immunoglobulins (g/L) } \\
\hline $\lg G$ & 2.9 & $3.2-11.5$ \\
\hline $\lg M$ & 0.1 & $0.5-1.9$ \\
\hline $\lg A$ & 0.1 & $0.0-0.9$ \\
\hline \multirow[t]{2}{*}{ Anti-tetanus toxoid IgG (IU/mL) } & $>7.0$ & $>0.1$ \\
\hline & (\% lymphocytes/control) & \\
\hline $\mathrm{CD}^{+} / \mathrm{CD} 45 \mathrm{RO}^{+}$ & 51.0 & - \\
\hline $\mathrm{CD}^{+} / \mathrm{CD} 45 \mathrm{RA}^{+}$ & 29.6 & - \\
\hline $\mathrm{CD}^{+} / \mathrm{CD} 45 \mathrm{RO}^{+}$ & 38.2 & - \\
\hline $\mathrm{CD}^{+} / \mathrm{CD} 45 \mathrm{RA}^{+}$ & 6.3 & - \\
\hline
\end{tabular}


treatment. She is otherwise well and is growing and developing appropriately for her age. She is currently given Pneumocystis Jiroveci (PJP) prophylaxis, and hematopoietic stem cell transplantation (HSCT) has been offered.

\section{Immune evaluation}

Since birth, the patient has had persistent lymphopenia as well as neutropenia. Immune work up further revealed a reduction in $\mathrm{CD} 19^{+}, \mathrm{CD} 4^{+}$, and $\mathrm{CD} 8^{+}$cells, with a relatively more profound $\mathrm{CD} 8^{+}$cell lymphopenia and an increased CD4:CD8 ratio (Table 1). TCRV $\beta$ analysis for clonality revealed mild expansion of $2 \mathrm{CD}^{+}$clones, while analysis of $\mathrm{CD}^{+}$clones was insignificant due to CD8 lymphopenia (Figure 1). Over time, the patient developed a mild reduction in NK cell counts as well. She also had reduced number of $\mathrm{CD} 4{ }^{+} \mathrm{CD} 45 \mathrm{Ra}^{+}$naïve $\mathrm{T}$ cells. $\mathrm{T}$ cell responses to mitogens were normal. Her humoral work up showed hypogammaglobulinemia with good specific response to tetanus vaccine. An initial TREC value was recorded at 42 copies $/ 3 \mu \mathrm{L}$. A repeat test from the same dried blood sample was abnormal at 17 copies $/ 3 \mu \mathrm{L}$ (cut off values $>75$ copies $/ 3 \mu \mathrm{L}$ ). Whole blood TREC were also low at 382 copies $/ 0.5 \mu$ g DNA (Table 1). Screening for TBX deletion and purine profile was normal. Maternal immune work up was done and revealed consistent neutropenia and B cell lymphopenia.

\section{Genetic diagnosis}

Whole exome sequencing identified a novel homozygous mutation in CORO1A: c.601C > T p.Arg201Cys (Figure 2), and was further confirmed by Sanger sequencing. This mutation is located in the tryptophan-aspartate (WD) repeat-containing element of CORO1A (Figure 3), which is thought to facilitate


Figure 1: TCRV $\beta$ repertoire. TCRV $\beta$ analysis for clonality revealed mild expansion of $2 \mathrm{CD} 4^{+}$ clones as well as $2 \mathrm{CD} 8^{+}$clones. 
the formation of heterotrimeric or multiprotein complexes. The patient's mother was found to be a heterozygous carrier. Western blotting confirmed the

COR01A

WT



Figure 2: Homozygous mutation in CORO1A. Electropherogram of the wild-type (WT; upper panel) sequence and novel homozygous mutation detected in the patient, c.601C>T (lower panel), in the CORO1A gene. complete lack of coronin $1 \mathrm{~A}$ protein expression in the patient (Figure 4).

\section{Discussion}

We report here the first coronin 1A deficient patient detected by positive NBS for SCID. This patient presented with leukopenia and neutropenia, but is currently doing clinically well at 14 months of age with no severe or recurrent infections. Previous reports show great variability in clinical presentations, ranging from patients presenting as severe combined immunodeficiency and severe vaccine-associated varicella infection (Shiow et al. 2008), through patients presenting with EBV related lymphoproliferation at a young age (Moshous et al. 2013) and yet later onset of disease, at 7 years of age (Stray-Pedersen et al. 2014).

All patients reported thus far had $\mathrm{T}$ cell lymphopenia (Shiow et al. 2008; Moshous et al. 2013; Stray-Pedersen et al. 2014). Another feature common to most patients is the severe reduction in $C D 45 \mathrm{Ra}^{+}$naïve T cells (Moshous et al. 2013; Moshous and de Villartay 2014; Stray-Pedersen et al. 2014) suggesting a role of coronin $1 \mathrm{~A}$ in mature $\mathrm{T}$ cell survival or thymocyte development. However, B and NK cell counts, T cell responses to mitogen and antigens, as well as humoral function are all variable among patients (Shiow et al. 2008; Moshous et al. 2013; Mace and Orange 2014; Stray-Pedersen et al. 2014). One patient (Mace and

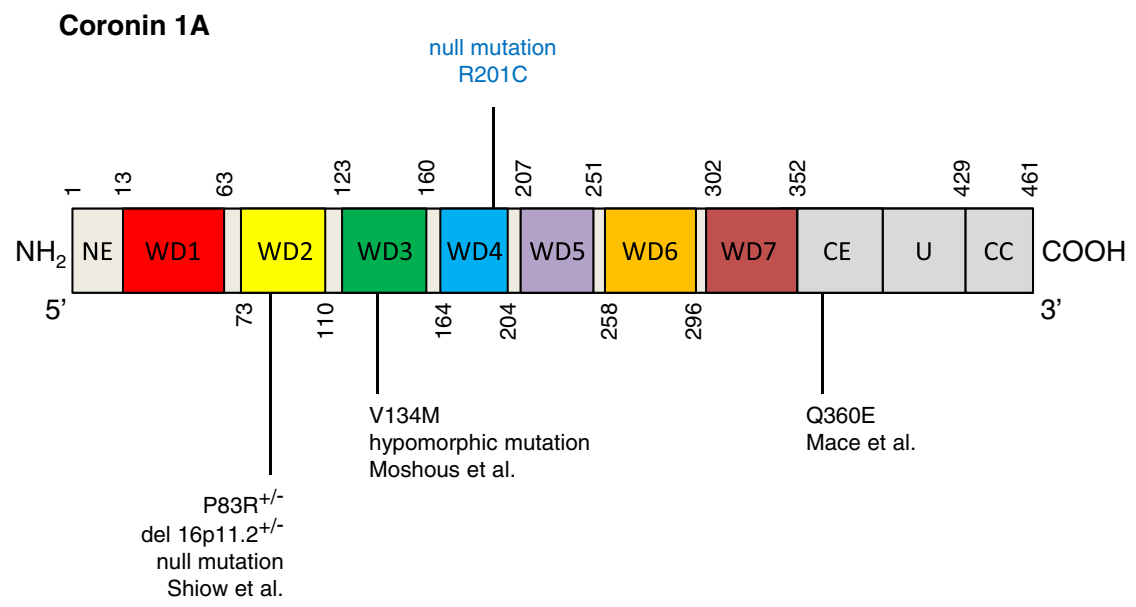

Figure 3: Localization of R201C mutation in WD repeat of Coronin $1 \mathrm{~A}$. Schematic representation of Coronin $1 \mathrm{~A}$ protein. The major structural domains are depicted: $\mathrm{CC}$, coiled coil domain; $\mathrm{CE}, \mathrm{C}$-terminal extension; $\mathrm{NE}, \mathrm{N}$-terminal extension; $\mathrm{U}$, unique region. The $7 \mathrm{WD}$ (tryptophan-aspartate) repeat domains forms a 7-bladed propeller. The novel c.601C $>\mathrm{T}$ homozygous mutation resulting in amino acid change p.Arg201Cys (R201C) is a loss of function mutation. 


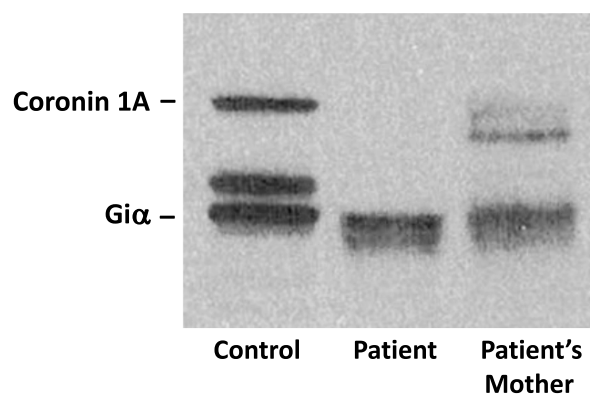

Figure 4: Analysis of Coronin 1A protein expression by western blotting. Complete absence of Coronin 1A protein expression is apparent in the patient. The patient's mother, a heterozygous carrier of the same mutation, has lower expression of protein compared to an unrelated control. Gi $\alpha$ is shown as loading control.

Orange 2014) was described to have abnormalities in NK cytotoxic function.

A genotype-phenotype correlation was postulated previously (Moshous and de Villartay 2014). However, the finding of a kindred with late onset disease and a null homozygous mutation (Stray-Pedersen et al. 2014) make any assumptions on such a correlation difficult.

Early studies on coronin 1A in phagocytes indicated an important role in the rearrangement of actin and regulation of $\mathrm{p} 40^{\text {phox }}$, a component of the NADPH oxidase (Grogan et al. 1997). Defective NADPH oxidase function, which is responsible for production of microbicidal superoxide and reactive oxygen species, leads to chronic granulomatous disease. Binding studies show that coronin $1 \mathrm{~A}$ associates with the C-terminal region of $\mathrm{p} 40^{\text {phox }}$. In the absence of its binding partner, coronin $1 \mathrm{~A}$ and $\mathrm{F}$-actin fail to rearrange during phagocytosis. Indeed, coronin $1 \mathrm{~A}$ has also been shown to regulate other aspects of neutrophil biology, including trafficking and apoptosis. In murine models of coronin 1A deficiency, aberrant accumulation of lymphocyte-function associated antigen 1 , needed to transition neutrophils from being firmly adherent to migratory, impairs leukocyte movement to sites of inflammation (Pick et al. 2017). Coronin 1A has also been identified by proteomic analysis to be involved in neutrophil apoptosis (Moriceau et al. 2009). Overexpression was associated with a lower rate of apoptosis due in part to delayed phosphatidylserine externalization, as shown in patients with cystic fibrosis. Functional analysis of neutrophils was not performed in our patient, however, one could hypothesize that the loss of coronin $1 \mathrm{~A}$ expression may have resulted in dysregulated apoptosis and innate defense against infections.

We report here the first case of coronin 1A deficiency presenting as a clinically asymptomatic positive NBS for SCID. As the newborn TREC assay for screening for SCID is gaining worldwide prevalence, we might see an increase in diagnoses of coronin $1 \mathrm{~A}$ as well as other combined immunodeficiencies and a broadening of the clinical spectrum of these conditions. Most combined immunodeficiencies are not diagnosed by the various NBS programs, whose purpose is to provide timely diagnosis and treatment only to the most severe cases of $\mathrm{T}$ cell deficiencies. As combined immunodeficiencies have a wide spectrum of disease severity, often within the same genetic entity, one would expect for the more severe presentations within the spectrum of disease to be diagnosed by low newborn TREC results. Whether this early recognition will result in an improved prognosis remains to be proven. The cutoff of a specific NBS program for reporting abnormal results, and the algorithm for investigating these results, also affect the capture rate of non-SCID $\mathrm{T}$ cell lymphopenias. This must be weighed against the resources in the specific program for follow up and investigation of these newborns.

Our patient presented with severe neutropenia along with her lymphopenia. This finding, which is also consistent in her asymptomatic mother, has not been previously reported in coronin $1 \mathrm{~A}$ deficiency. Although coronin $1 \mathrm{~A}$ is known to function as a regulator of cytoskeleton, it was not reported to affect neutrophil function (Combaluzier and Pieters 2009).

\section{Summary}

We hereby report the first case of coronin 1A deficiency presenting in a well newborn as part of the NBS program. Coronin $1 \mathrm{~A}$ is a rare combined immunodeficiency, and the few cases reported in the literature had a variable although detrimental clinical course. As our patient is currently well, we are confronted with one of the challenges posed by early diagnosis of rare diseases, i.e., the inability of predicting prognosis, and 
thus the difficulty in recommending a potentially risky procedure, such as HSCT.

\section{REFERENCES}

Accetta Pedersen, D.J., Verbsky, J., and Routes, J.M. 2011. Screening newborns for primary T-cell immunodeficiencies: Consensus and controversy. Expert Rev. Clin. Immunol. 7(6):761-768. PMID: 22014017. doi: 10.1586/eci.11.25.

Ahmed, Z., Shaw, G., Sharma, V.P., Yang, C., McGowan, E., and Dickson, D.W. 2007. Actin-binding proteins coronin-1a and IBA-1 are effective microglial markers for immunohistochemistry. J. Histochem. Cytochem. 55(7):687-700. PMID: 17341475. doi: 10.1369/jhc. 6A7156.2007.

Baker, M.W., Laessig, R.H., Katcher, M.L., Routes, J.M., Grossman, W.J., Verbsky, J., Kurtycz, D.F., and Brokopp, C.D. 2010. Implementing routine testing for severe combined immunodeficiency within Wisconsin's newborn screening program. Public Health Rep. 125(2_suppl):88-95. PMID: 20518449. doi: $10.1177 / 00333549101250$ S211.

Blom, M., Pico-Knijnenburg, I., Sijne-van Veen, M., Boelen, A., Bredius, R.G.M., van der Burg, M., and Schielen, P.C.J.I. 2017. An evaluation of the TREC assay with regard to the integration of SCID screening into the Dutch newborn screening program. Clin. Immunol. 180:106-110. PMID: 28487086. doi: 10.1016/j.clim.2017.05.007.

Combaluzier, B., and Pieters, J. 2009. Chemotaxis and phagocytosis in neutrophils is independent of coronin 1. J. Immunol. 182(5):2745-2752. PMID: 19234169. doi: 10.4049/jimmunol.0801812.

Cross, C. 2013. Ontario newborns now screened for SCID. CMAJ. 185(13):E616. PMID: 23979867. doi: 10.1503/cmaj.109-4580.

Föger, N., Rangell, L., Danilenko, D.M., and Chan, A.C. 2006. Requirement for coronin 1 in T lymphocyte trafficking and cellular homeostasis. Science. 313(5788):839-842. PMID: 16902139. doi: 10.1126/ science.1130563.

Grogan, A., Reeves, E., Keep, N., Wientjes, F., Totty, N. F., Burlingame, A.L., Hsuan, J.J., and Segal, A.W. 1997. Cytosolic phox proteins interact with and regulate the assembly of coronin in neutrophils. J. Cell Sci. 110(Pt 24):3071-3081. PMID: 9365277.

Jayachandran, R., Sundaramurthy, V., Combaluzier, B., Mueller, P., Korf, H., Huygen, K., Miyazaki, T., Albrecht, I., Massner, J., and Pieters, J. 2007. Survival of mycobacteria in macrophages is mediated by coronin 1-dependent activation of calcineurin. Cell. 130(1):37-50. PMID: 17632055. doi: 10.1016/j.cell. 2007.04.043.

Kanegae, M.P., Barreiros, L.A., Mazzucchelli, J.T., Hadachi, S.M., de Figueiredo Ferreira Guilhoto, L.M., Acquesta, A.L., Genov, I.R., Holanda, S.M., Di Gesu, R. S., Goulart, A.L., Dos Santos, A.M., Bellesi, N., CostaCarvalho, B.T., and Condino-Neto, A. 2016. Neonatal screening for severe combined immunodeficiency in Brazil. J. Pediatr. 92(4):374-380. PMID: 27207231. doi: 10.1016/j.jped.2015.10.006.

Kwan, A., Abraham, R.S., Currier, R., Brower, A., Andruszewski, K., Abbott, J.K., Baker, M., Ballow, M., Bartoshesky, L.E., Bonilla, F.A., Brokopp, C., Brooks, E., Caggana, M., Celestin, J., Church, J.A., Comeau, A.M., Connelly, J.A., Cowan, M.J., Cunningham-Rundles, C., Dasu, T., Dave, N., De La Morena, M.T., Duffner, U., Fong, C.T., Forbes, L., Freedenberg, D., Gelfand, E.W., Hale, J.E., Hanson, I. C., Hay, B.N., Hu, D., Infante, A., Johnson, D., Kapoor, N., Kay, D.M., Kohn, D.B., Lee, R., Lehman, H., Lin, Z., Lorey, F., Abdel-Mageed, A., Manning, A., McGhee, S., Moore, T.B., Naides, S.J., Notarangelo, L.D., Orange, J.S., Pai, S.Y., Porteus, M., Rodriguez, R., Romberg, N., Routes, J., Ruehle, M., Rubenstein, A., Saavedra-Matiz, C.A., Scott, G., Scott, P.M., Secord, E., Seroogy, C., Shearer, W.T., Siegel, S., Silvers, S.K., Stiehm, E.R., Sugerman, R.W., Sullivan, J.L., Tanksley, S., Tierce, M.L., IV, Verbsky, J., Vogel, B., Walker, R., Walkovich, K., Walter, J.E., Wasserman, R.L., Watson, M.S., Weinberg, G.A., Weiner, L.B., Wood, H., Yates, A.B., Puck, J.M., and Bonagura, V.R. 2014. Newborn screening for severe combined immunodeficiency in 11 screening programs in the United States. JAMA. 312(7):729-738. PMID: 25138334. doi: 10.1001/jama.2014.9132.

Mace, E.M., and Orange, J.S. 2014. Lytic immune synapse function requires filamentous actin deconstruction by Coronin 1A. Proc. Natl. Acad. Sci. USA. 111(18):6708-6713. PMID: 24760828. doi: 10.1073/ pnas.1314975111.

Martorella, M., Barford, K., Winkler, B., and Deppmann, C.D. 2017. Emergent role of coronin-1a in neuronal signaling. Vitam. Horm. 104:113-131. PMID: 28215292. doi: 10.1016/bs.vh.2016.10.002.

Moriceau, S., Kantari, C., Mocek, J., Davezac, N., Gabillet, J., Guerrera, I.C., Brouillard, F., Tondelier, D., Sermet-Gaudelus, I., Danel, C., Lenoir, G., Daniel, S., Edelman, A., and Witko-Sarsat, V. 2009. Coronin-1 is associated with neutrophil survival and is cleaved during apoptosis: Potential implication in 
neutrophils from cystic fibrosis patients. J. Immunol. 182(11):7254-7263. PMID: 19454722. doi: 10.4049/ jimmunol.0803312.

Moshous, D., and de Villartay, J.-P. 2014. The expanding spectrum of human coronin 1A deficiency. Curr. Allergy Asthma Rep. 14(12):481. PMID: 25269405. doi: 10.1007/s11882-014-0481-1.

Moshous, D., Martin, E., Carpentier, W., Lim, A., Callebaut, I., Canioni, D., Hauck, F., Majewski, J., Schwartzentruber, J., Nitschke, P., Sirvent, N., Frange, P., Picard, C., Blanche, S., Revy, P., Fischer, A., Latour, S., Jabado, N., and de Villartay, J.P. 2013. Whole-exome sequencing identifies Coronin-1A deficiency in 3 siblings with immunodeficiency and EBVassociated B-cell lymphoproliferation. J. Allergy Clin. Immunol. 131(6):1594-1603.e9. PMID: 23522482. doi: 10.1016/j.jaci.2013.01.042.

Oku, T., Itoh, S., Okano, M., Suzuki, A., Suzuki, K., Nakajin, S., Tsuji, T., Nauseef, W.M., and Toyoshima, S. 2003. Two regions responsible for the actin binding of p57, a mammalian coronin family actin-binding protein. Biol. Pharm. Bull. 26(4): 409-416. PMID: 12673016. doi: 10.1248/bpb.26.409.

Pick, R., Begandt, D., Stocker, T.J., Salvermoser, M., Thome, S., Bottcher, R.T., Montanez, E., Harrison, U., Forne, I., Khandoga, A.G., Coletti, R., Weckbach, L.T., Brechtefeld, D., Haas, R., Imhof, A., Massberg, S., Sperandio, M., and Walzog, B. 2017. Coronin 1A, a novel player in integrin biology, controls neutrophil trafficking in innate immunity. Blood. 130(7):847-858. PMID: 28615221. doi: 10.1182/blood-2016-11-749622.

Roifman, C.M., Somech, R., Kavadas, F., Pires, L., Nahum, A., Dalal, I., and Grunebaum, E. 2012. Defining combined immunodeficiency. J. Allergy Clin. Immunol. 130(1):177-183. PMID: 22664165. doi: $10.1016 /$ j.jaci.2012.04.029.

Rybakin, V., and Clemen, C.S. 2005. Coronin proteins as multifunctional regulators of the cytoskeleton and membrane trafficking. BioEssays. 27(6):625-632. PMID: 15892111. doi: 10.1002/bies.20235.

Sharfe, N., Nahum, A., Newell, A., Dadi, H., Ngan, B., Pereira, S.L., Herbrick, J.A., and Roifman, C.M. 2014. Fatal combined immunodeficiency associated with heterozygous mutation in STAT1. J. Allergy Clin. Immunol. 133(3):807-817. PMID: 24239102. doi: $10.1016 /$ j.jaci.2013.09.032.

Shiow, L.R., Roadcap, D.W., Paris, K., Watson, S.R., Grigorova, I.L., Lebet, T., An, J., Xu, Y., Jenne, C.N., Föger, N., Sorensen, R.U., Goodnow, C.C., Bear, J.E., Puck, J.M., and Cyster, J.G. 2008. The actin regulator coronin $1 \mathrm{~A}$ is mutant in a thymic egress-deficient mouse strain and in a patient with severe combined immunodeficiency. Nat. Immunol. 9(11):1307-1315. PMID: 18836449. doi: 10.1038/ni.1662.

Shiow, L.R., Paris, K., Akana, M.C., Cyster, J.G., Sorensen, R.U., and Puck, J.M. 2009. Severe combined immunodeficiency (SCID) and attention deficit hyperactivity disorder (ADHD) associated with a coronin-1A mutation and a chromosome $16 \mathrm{p} 11.2$ deletion. Clin. Immunol. 131(1):24-30. PMID: 19097825. doi: 10.1016/j.clim.2008.11.002.

Stavropoulos, D.J., Merico, D., Jobling, R., Bowdin, S., Monfared, N., Thiruvahindrapuram, B., Nalpathamkalam, T., Pellecchia, G., Yuen, R.K.C., Szego, M.J., Hayeems, R.Z., Shaul, R.Z., Brudno, M., Girdea, M., Frey, B., Alipanahi, B., Ahmed, S., BabulHirji, R., Porras, R.B., Carter, M.T., Chad, L., Chaudhry, A., Chitayat, D., Doust, S.J., Cytrynbaum, C., Dupuis, L., Ejaz, R., Fishman, L., Guerin, A., Hashemi, B., Helal, M., Hewson, S., Inbar-Feigenberg, M., Kannu, P., Karp, N., Kim, R., Kronick, J., Liston, E., MacDonald, H., Mercimek-Mahmutoglu, S., Mendoza-Londono, R., Nasr, E., Nimmo, G., Parkinson, N., Quercia, N., Raiman, J., Roifman, M., Schulze, A., Shugar, A., Shuman, C., Sinajon, P., Siriwardena, K., Weksberg, R., Yoon, G., Carew, C., Erickson, R., Leach, R.A., Klein, R., Ray, P.N., Meyn, M.S., Scherer, S.W., Cohn, R.D., and Marshall, C.R. 2016. Whole-genome sequencing expands diagnostic utility and improves clinical management in paediatric medicine. NPJ Genom. Med. 1(1):15012. PMID: 28567303. doi: 10.1038/npjgenmed.2015.12.

Stray-Pedersen, A., Jouanguy, E., Crequer, A., Bertuch, A.A., Brown, B.S., Jhangiani, S.N., Muzny, D.M., Gambin, T., Sorte, H., Sasa, G., Metry, D., Campbell, J., Sockrider, M.M., Dishop, M.K., Scollard, D.M., Gibbs, R.A., Mace, E.M., Orange, J.S., Lupski, J.R., Casanova, J.L., and Noroski, L.M. 2014. Compound heterozygous CORO1A mutations in siblings with a mucocutaneous-immunodeficiency syndrome of epidermodysplasia verruciformis-HPV, molluscum contagiosum and granulomatous tuberculoid leprosy. J. Clin. Immunol. 34(7):871-890. PMID: 25073507. doi: 10.1007/s10875-014-0074-8.

Suzuki, K., Nishihata, J., Arai, Y., Honma, N., Yamamoto, K., Irimura, T., and Toyoshima, S. 1995. Molecular cloning of a novel actin-binding protein, p57, with a WD repeat and a leucine zipper motif. FEBS Lett. 364(3):283-288. PMID: 7758584. doi: 10.1016/0014-5793(95)00393-N.

van der Spek, J., Groenwold, R.H., van der Burg, M., and van Montfrans, J.M. 2015. TREC based newborn screening for severe combined immunodeficiency disease: A systematic review. J. Clin. Immunol. 
35(4):416-430. PMID: 25893636. doi: 10.1007/ s10875-015-0152-6.

Wang, K., Li, M., and Hakonarson, H. 2010. ANNOVAR: Functional annotation of genetic variants from high-throughput sequencing data. Nucleic Acids Res. 38(16):e164. PMID: 20601685. doi: 10.1093/nar/gkq603.
Xavier, C.P., Eichinger, L., Fernandez, M.P., Morgan, R.O., and Clemen, C.S. 2008. Evolutionary and functional diversity of coronin proteins. In The coronin family of proteins. Subcellular biochemistry. Edited by C.S. Clemen, L. Eichinger, and V. Rybakin. New York, NY, USA: Springer New York. Vol. 48, pp. 98-109. doi: 10.1007/978-0-387-09595-0_9. 